\title{
Principal Characters in Encounter
}

CHO SIN-CH'ÓL A packhorse driver who befriends Ha-sang during Ha-sang's first trip to Peking. Christian name, Charles. Martyred in 1839 and canonized in 1984 .

CHo suk A nephew of Cho Tong-sŏm, husband of Kwŏn Teresa.

Christian name, Peter. Martyred in 1819.

CHO TONG-SÒ An exiled scholar. The teacher of Ha-sang and a friend of Yak-chong. Christian name, Justino.

CHŎNG HAG-YŎN Tasan's eldest son.

CHÖNG HAG-YU Tasan's second son.

CHÖNG HA-SANG 1795-1839. Son of Yak-chong, a nephew of Tasan. Saint Paul Ha-sang Chŏng. Martyred in 1839 , canonized in 1984 .

CHONG YAG-YONG $1762-1836$. Tasan. The youngest of the Chŏng brothers. Variously known as Yŏyudang, Mugŭkkwanin, Chahansanin. Christian name, Johann.

CHŎNG YAK-CHŎN 1758-1816. Tasan's second brother.

CHŎNG YAK-CHONG 1760-1801. Tasan's third brother. Ha-sang's father. Christian name, Augustine. Martyred in 1801. CHÓNG YAK-HYON Tasan's eldest brother.

CHOU WEN-MU $175^{2-1} 801$. A Chinese priest, the first Catholic missionary to arrive in Korea (in 1795). Martyred in 1801. HONG, MATTEO The innkeeper at the bamboo grove. Also known as Hŏ.

HONG-NIM A daughter of Tasan by P'yo-nyŏ, born during Tasan's exile. 
HWANG SA-YOัNG A disciple of Chŏng Yak-chong. The writer of

"Silk Letter" in 1801. Martyred in 1801.

HYEJANG 1772-1811. An eminent Buddhist monk, Tasan's friend and disciple during his exile.

KIM CHÖNG-SUN, QUEEN DOWAGER 1745-1805. Queen of King Yongjo. As the young King Sunjo's regent, promulgates the Edict of Catholic Eradication; responsible for the Persecution of 1801 .

KWÓN HO-SIN Father of Mae-a, Nan-a, and Kug-a.

KWÖN KUG-A The youngest daughter of Kwōn Ho-sin. Adopted into the household of the Overseer of the Local Agency in Imsil, where she is named Kung-nim. Christian name, Juliette. KWŌN NAN-A Second daughter of Kwŏn Ho-sin. Adopted by shaman Man-nyŏn, who names her Butterfly. Christian name, Cecilia. Martyred in 1825 .

KWŎN MAE-A The eldest daughter of Kwŏn Ho-sin. Christian name, Maria. She goes to live with the former palace lady Myǒng-sim. Martyred in $\mathbf{1 8 2 5}$.

KWÓn TERESA Daughter of Kwŏn Il-sin, Francesco Xavier, one of the first Korean Christians. Martyred in 1819 .

MAN-NYON A hereditary shaman and adoptive mother of Kwŏn Nan-a, Butterfly.

MYÓNG-SIM A daughter of a chungin apothecary, recruited to become a palace lady. Christian name, Teresa. Martyred in 1825 .

P'yo An old man who befriends Tasan when he first comes to

Kangjin and introduces him to Hyejang.

P'YO-NYO Daughter of P'yo, a woman Tasan lives with during his exile. Mother of Hong-nim.

SÜNG NAK-CHONG A trusted servant of Kwŏn Ho-sin, who betrays the Kwon family and causes the family's tragedy.

Christian name, Pius.

YI CHI-YON 1777-1841. The deputy envoy during Ha-sang's first trip to Peking; later Ha-sang's prosecutor. Before his death he was the Prime Minister of the Right.

YI KI-GYONG Once Tasan's friend, who studied Catholicism with him; later turning Tasan's adversary, pursues him to his banishment. 
YI SŬNG-HUN 1756-1801. Husband of Tasan's sister, also known as Manch'ŏn. The first baptized Catholic in Korea (1794).

Christian name, Peter. Martyred in 1801.

YU CHIN-GIL A chungin translator. Christian name, Augustine.

Martyred in 1839 and canonized in 1984 .

YUN CHONG-SIM 1793-?. One of Tasan's eighteen disciples during Tasan's exile in Kyuldong. 
This page intentionally left blank 